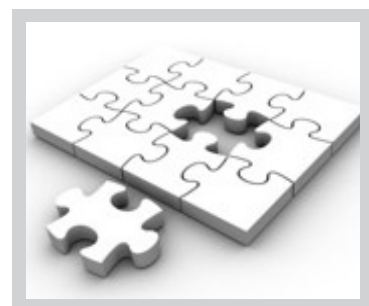

In 'n poging om die keuse van geskikte eweknieevalueerders vir die Suid-Afrikaanse Tydskrif vir Natuurwetenskap en Tegnologie te vergemaklik, versoek ons $u$ om 'n oomblik af te staan om u elektroniese portfolio by http:/ / www.satnt. ac.za op datum te bring.

Dit sal ons in staat stel om u belangstellingsveld en kundigheid beter te takseer sodat die voorgelegde manuskripte aan die geskikste eweknieevalueerders toegeken kan word. Indien u belangstel om 'n evalueerder te word, word $u$ versoek om die tydskrif se webwerf te besoek om as evalueerder te registreer. Om toegang tot $\mathrm{u}$ besonderhede op die webwerf te verkry, moet die volgende stappe gevolg word:

1. Teken vir die aanlynjoernaal in by http://www.satnt.

ac.za

2. Kies in u 'user home' [http://www.satnt.ac.za/ index.php/satnt/user] 'edit my profile' onder die opskrif 'my account' en tik alle relevante besonderhede, bio-verklaring en evalueringsbelangstellings in.

\section{Dit is goeie}

evalueerderspraktyk om u persoonlike besonderhede gereeld op datum te bring om te verseker dat ons gedurende $u$ termyn as evalueerder vir die Suid-Afrikaanse Tydskrif vir Natuurwetenskap en Tegnologie met $\mathrm{u}$ in aanraking kan kom.

Moet asseblief nie huiwer om ons te kontak vir verdere navrae nie.

\section{Uitgewer:}

publishing@aosis.co.za

Tel: +27 219752602

Fax: +27 219754635

\title{
Erkenning aan evalueerders
}

Die redaksionele span van die Suid-Afrikaanse Tydskrif vir Natuurwetenskap en Tegnologie erken hiermee die waardevolle, belangrike rol wat eweknie-evalueerders tydens die algehele publikasiesproses vervul - nie alleen in die vorming van individuele manuskripte nie, maar ook in die vestiging van die kredietwaardigheid en aansien van ons joernaal. Ons is daartoe verbind om alle oorspronklike, innoverende bydraes, wat vir publikasie aanvaar word, tydig te publiseer. Daarom is die identifisering en keuse van kundige evalueerders, met belangstelling in die onderwerpe wat deur elke manuskrip gedek word, 'n onontbeerlike element om 'n tydige, produktiewe eweknieevalueringsproses te verseker.

Ons wil graag van hierdie geleentheid gebruik maak om die volgende evalueerders vir hulle bydrae tot die vorming van hierdie uitgawe van die Suid-Afrikaanse Tydskrif vir Natuurwetenskap en Tegnologie te bedank:

Andre Venter

Annemarie Hattingh

Burgert A. Senekal

Chris P.H. Myburgh

Christo P. van der Westhuizen

Corné Kruger

Eric Eberlein

Erna R. du Toit

Esbeth van Dyk

Estelle Gaigher

Fanus Venter

Francois van der Westhuizen

Gerrit H. Stols

Gillian Corken

Ishaku L. Elisha

Jacobus N. Eloff

Jan H. Havenga

Japie J. van Tonder

Japie Engelbrecht

Jeanne Kriek

Jerry Shai

\author{
Josef J. de Beer \\ Leila Goosen \\ Linda van Ryneveld \\ Lizette de Jager \\ Lyndy J. McGaw \\ Margaretha Roux \\ Max Braun \\ Muna Mohammed \\ Oppel B.W. Greeff \\ Peet du Toit \\ Prudence Kayoka \\ Rian de Villiers \\ Ronel Ferreira \\ Roxanne Bailey \\ Rudolph Botha \\ Salome Mahlo \\ Schalk W.P. Engelbrecht \\ Vanessa Steenkamp \\ William J. Fraser \\ Wynand J. Boshoff
}

Ons waardeer $u$ tyd en bydrae tot die suksevolle evaluasie van die artikels. 